85.7 and $77.8^{\circ}$ (clonazepam) have been found (Bandoli \& Clemente, 1976; Chananont, Hamor \& Martin, 1979).

Temazepam molecules are not too densely packed in the crystal. The shortest intermolecular distances are 2.88 for $\mathrm{O}\left(3^{A}\right) \cdots \mathrm{O}\left(2^{A}\right)$ [the second atom at $2-x, 1-$ $y, 1-z], 2 \cdot 87 \AA$ for $\mathrm{N}\left(4^{C}\right) \ldots \mathrm{O}\left(3^{C}\right)[1-x, 2-y, 2-$ $z$, and for transformation [ $1-x, 2-y, 1-z] 3 \cdot 21 \AA$ for $\mathrm{O}\left(3^{A}\right) \cdots \mathrm{O}\left(2^{B}\right), 3.02 \AA$ for $\mathrm{O}\left(3^{B}\right) \ldots \mathrm{O}\left(3^{A}\right)$ and $3.08 \AA$ for $\mathrm{O}\left(2^{B}\right) \cdots \mathrm{N}\left(4^{A}\right)$. Although some lengths suggest the presence of hydrogen bonds, a detailed analysis of the $\mathrm{O}-\mathrm{H}$ bond directions and hydrogenproton-acceptor distances brings doubt to the suggestion. Even if an $\mathrm{O}-\mathrm{H}$ bond length of about $1 \AA$ is assumed $[0.54(4), 0.52(4)$ and $0.61(4) \AA$ were obtained after refinement for molecules $A, B$ and $C$, while the mean $\mathrm{C}-\mathrm{H}$ bond lengths are $1.00(A)$, $1.01(B)$ and $1.02 \AA(C)]$, the presence of hydrogen bonds, both inter- and intramolecular, is questionable. Thus, in the case of molecule $A, \mathrm{O}(3) \cdots \mathrm{O}(2)$ and $\mathrm{O}(3) \cdots \mathrm{N}(4)$ intramolecular distances are $2.702(4)$ and 2.346 (4) $\AA$, whereas $\mathrm{H}(1) \ldots \mathrm{O}(2)$ and $\mathrm{H}(1) \ldots$ $\mathrm{N}(4)$ are 2.60 (4) and 2.51 (5) $\AA$; and after 'lengthening' of the $\mathrm{O}-\mathrm{H}$ bond, the distances are $2.54 \AA$ for both possible acceptors. For molecule $B$ analogous distances are $2.614(4)$ and $2.384(4), 2.91(4)$ and $2.16(4)$ $[\mathrm{H} \cdots X]$, and 3.20 and $2 \cdot 13 \AA$ after 'correcting' the $\mathrm{O}-\mathrm{H}$ distance; for molecule $C 2.751$ (4) and 2.340 (5) $[X \cdots X], 3.35(4)$ and $2 \cdot 56(5)[\mathrm{H} \cdots X]$, and 3.73 and $2.36 \AA$. The shortest intermolecular $\mathrm{H} \cdots X(\mathrm{O}, \mathrm{N})$ distance involves $\mathrm{O}\left(3^{A}\right) \cdots \mathrm{O}\left(2^{A}\right)$ with $\mathrm{H}(1) \cdots \mathrm{O}(2)$ distances of 2.05 and 2.35 (4) $\AA$ (with and without correction of the $\mathrm{H}$-atom position).
The authors are indebted to $\mathrm{Mr} \mathrm{M}$. Werfer for crystals and Mrs K. Kozlowska for technical assistance. This research was supported by project MR.I.9 from the Polish Academy of Sciences.

\section{References}

Bandoli, G. \& Clemente, D. A. (1976). J. Chem. Soc. Perkin Trans. 2, pp. 413-418.

Camerman, A. \& Camerman, N. (1970). Science, 168, 1457-1458.

Camerman, A. \& Camerman, N. (1972). J. Am. Chem. Soc. 94, 268-272.

Chananont, P., Hamor, T. A. \& Martin, I. L. (1979). Cryst. Struct. Commun. 8, 393-400.

Doyle, P. A. \& Turner, P. S. (1968). Acta Cryst. A24, 390-397.

DuAx, W. L. \& Norton, D. A. (1975). Atlas of Steroid Structure, pp. 16-22. New York: Plenum.

Galdecki, Z., GlówKa, M. L., KozlowsKa, K. \& Werfel, M. (1976). Rocz. Chem. 50, 2227-2228.

Germain, G., Main, P. \& Woolfson, M. M. (1971). Acta Cryst. A27, 368-376.

Gilli, G., Bertolasi, V., Sacerdoti, M. \& Borea, P. A. (1977). Acta Cryst. B33, 2664-2667.

Gilli, G., Bertolasi, V., Sacerdoti, M. \& Borea, P. A. (1978a). Acta Cryst. B34, 2826-2829.

Gilli, G., Bertolasi, V., Sacerdoti, M. \& Borea, P. A. (1978b). Acta Cryst. B34, 3793-3795.

International Tables for X-ray Crystallography (1962). Vol. III, pp. 202-203. Birmingham: Kynoch Press.

Sternbach, L. H. SANCilio, F. D. \& Blount, J. F. (1974). J. Med. Chem. 17, 374-377.

Stewart, J. M., Kundell, F. A. \& Baldwin, J. C. (1970). The XRAY 70 system. Computer Science Center, Univ. of Maryland, College Park, Maryland.

Acta Cryst. (1980). B36, 3048-3052

\title{
The Structure of 1-Phenyl-4,5-(1,2-D-glucofurano)imidazolidin-2-one
}

\author{
By A. Conde, F. Bernier and R. Márquez \\ Departamento de Optica y Sección de Física del Centro Coordinado del CSIC, Universidad de Sevilla, Spain
}

(Received 20 March 1980; accepted 14 July 1980)

\begin{abstract}
The crystal structure of $\mathrm{C}_{13} \mathrm{H}_{16} \mathrm{~N}_{2} \mathrm{O}_{5}$ has been solved by direct methods. Crystal data are $a=9.033(1), b=$ $10.097(1), c=7.155$ (1) $\AA, \beta=105.92(1)^{\circ}, Z=2$, space group $P 2_{1}$ (from statistics). The final $R$ value for 1246 independent reflexions was 0.068 . The glucofurano-imidazolidine group adopts a cis form of coupling with a dihedral angle of $70 \cdot 2(6)^{\circ}$. The phenyl

0567-7408/80/123048.05\$01.00
\end{abstract}

substituent forms a dihedral angle of $15.1(6)^{\circ}$ with the imidazolidine ring plane. Intermolecular hydrogen bonds link molecules related by a screw axis to give helical chains parallel to $b$.

\section{Introduction}

The crystal structure of 1-phenyl-4,5-(1,2-Dglucofurano)imidazolidin-2-one

(C) 1980 International Union of Crystallography 


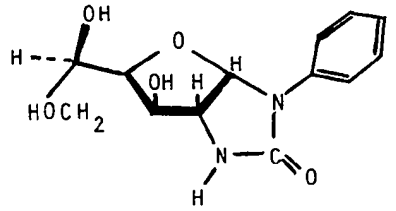

has been determined as part of a systematic structural investigation of compounds obtained by reaction of 2-amino-2-deoxy-D-glucose with alkyl (aryl) isothiocyanates carried out in the Organic Chemistry Department of this University. Previous research connected with this programme involved the X-ray structural analysis of some imidazole $\mathrm{C}$-nucleosides and glucofurano-imidazolidine compounds (Conde, LópezCastro \& Márquez, 1978). In earlier publications (Fernández-Bolaños, Garcia-González, Gasch \& Menéndez, 1963; Kruger \& Rudy, 1963; Fritz \& Wacker, 1968; García-González, Fernández-Bolaños \& Pradera, 1974) both furanoid and pyranoid structures were proposed for the sugar moieties of these compounds; here the furanoid form is established.

The structure determination of the title compound was suggested by Professor J. Fernandez-Bolaños in order to obtain detailed conformational and configurational information.

\section{Experimental}

The compound was supplied in the form of colourless needle-shaped prismatic crystals. Preliminary unit-cell dimensions and symmetry information were obtained from oscillation and Weissenberg photographs. The systematic absences ( $0 k 0$ with $k$ odd) suggested the possible space groups $P 2_{1}\left(C_{2}^{2}\right)$ and $P 2_{1} / m\left(C_{2 n}^{2}\right)$. As $Z=2, P 2$, was chosen. Accurate cell parameters were obtained by least-squares refinement of the $\theta$ values of 50 reflexions measured on the diffractometer. Other crystal data are: $V=627.5$ (1) $\AA^{3}, D_{c}=1.48, D_{m}=$ $1.49(1) \mathrm{Mg} \mathrm{m}^{-3}, F(000)=296, \mu(\mathrm{Cu} K \alpha)=0.92$ $\mathrm{mm}^{-1}$.

Intensity data were collected up to $\theta=65^{\circ}$ with an automated Siemens AED single-crystal diffractometer using $\mathrm{Ni}$-filtered $\mathrm{Cu}$ radiation and the $\omega-2 \theta$ scanning mode. 1246 independent reflexions with $I>2 \sigma(I)$ were considered as observed. Two standard reflexions were monitored periodically and subsequently used for scaling; no significant change was observed in the intensities of these reflexions during the data collection. The intensities were corrected for Lorentz and polarization effects but no absorption or extinction corrections were applied.

\section{Structure determination and refinement}

The structure was solved by multisolution weighted tangent-formula refinement (MULTAN 78; Main,
Table 1. Atomic fractional coordinates $\left(\times 10^{4}\right.$ for non-hydrogen atoms, $\times 10^{3}$ for hydrogen) and isotropic thermal parameters

The overall isotropic thermal parameter of the $\mathrm{H}$ atoms is $4 \AA^{2}$.

$\begin{array}{lcccc} & x & y & z & B\left(\AA^{2}\right) \\ \mathrm{O}(1) & 7003(4) & 5000 & 1287(6) & 3 \cdot 1(2) \\ \mathrm{O}(2) & 7718(5) & 9145(6) & -449(6) & 3 \cdot 7(2) \\ \mathrm{O}(3) & 8876(5) & 5129(6) & 5579(6) & 3 \cdot 9(2) \\ \mathrm{O}(4) & 10800(4) & 3517(6) & 3285(6) & 3 \cdot 3(2) \\ \mathrm{O}(5) & 9343(5) & 1398(6) & 1074(7) & 4 \cdot 0(2) \\ \mathrm{N}(1) & 6460(5) & 7197(6) & -23(7) & 3 \cdot 0(2) \\ \mathrm{N}(2) & 8166(6) & 8070(6) & 2493(7) & 3 \cdot 7(2) \\ \mathrm{C}(1) & 7484(6) & 8230(7) & 585(8) & 3 \cdot 2(3) \\ \mathrm{C}(2) & 6478(6) & 6299(7) & 1559(9) & 3 \cdot 2(3) \\ \mathrm{C}(3) & 7672(7) & 6896(7) & 3330(9) & 3 \cdot 4(3) \\ \mathrm{C}(4) & 8989(7) & 5841(7) & 3922(8) & 2 \cdot 9(3) \\ \mathrm{C}(5) & 8674(6) & 4972(7) & 2136(8) & 2 \cdot 8(3) \\ \mathrm{C}(6) & 5411(6) & 7052(8) & -1909(9) & 3 \cdot 0(3) \\ \mathrm{C}(7) & 4654(7) & 5831(8) & -2377(10) & 3 \cdot 7(3) \\ \mathrm{C}(8) & 3605(7) & 5663(9) & -4206(10) & 3 \cdot 9(3) \\ \mathrm{C}(9) & 3316(7) & 6661(9) & -5555(9) & 3 \cdot 7(3) \\ \mathrm{C}(10) & 4047(7) & 7874(8) & -5071(10) & 3 \cdot 8(3) \\ \mathrm{C}(11) & 5096(7) & 8068(8) & -3259(9) & 3 \cdot 7(3) \\ \mathrm{C}(12) & 9178(6) & 3531(7) & 2490(8) & 2 \cdot 9(3) \\ \mathrm{C}(13) & 8677(7) & 2710(8) & 654(9) & 3 \cdot 4(3) \\ \mathrm{H}(2) & 541(9) & 619(9) & 178(11) & \\ \mathrm{H}(3) & 725(10) & 714(9) & 459(12) & \\ \mathrm{H}(4) & 998(9) & 626(9) & 415(10) & \\ \mathrm{H}(5) & 934(9) & 555(9) & 114(12) & \\ \mathrm{H}(7) & 502(9) & 500(9) & -131(11) & \\ \mathrm{H}(8) & 310(9) & 481(9) & -478(12) & \\ \mathrm{H}(9) & 262(9) & 653(9) & -698(11) & \\ \mathrm{H}(10) & 357(8) & 860(9) & -623(11) & \\ \mathrm{H}(11) & 594(9) & 889(9) & -284(11) & \\ \mathrm{H}(12) & 881(9) & 311(9) & 356(11) & \\ \mathrm{H}(131) & 727(9) & 262(8) & -2(11) & \\ \mathrm{H}(132) & 908(8) & 309(9) & -54(11) & \\ \mathrm{H}(\mathrm{N} 2) & 914(9) & 872(9) & 343(11) & \\ \mathrm{H}(\mathrm{O} 3) & 932(9) & 489(9) & 628(11) & \\ \mathrm{H}(\mathrm{O} 4) & 1122(9) & 375(9) & 225(11) & \\ \mathrm{H}(\mathrm{O}) & 877(9) & 72(9) & 107(11) & \\ & & & & \\ & & & & \end{array}$

Hull, Lessinger, Germain, Declercq \& Woolfson, 1978) of 180 reflexions with $|E|>1.40$ (nine reflexions per non-hydrogen atom in the asymmetric unit). Scale and overall temperature factors $\left(B=3.4 \AA^{2}\right)$ were evaluated by the Wilson method. The values of the statistical averages of calculated normalized structure factors are 0.877 and 0.758 for $\langle|E|\rangle$ and \langle|$E^{2}-$ 11) respectively, which indicated the non-centrosymmetric space-group symmetry $P 2_{1}$.

An $E$ map with the phase set with the highest combined figure of merit revealed clearly the positions of all the non-hydrogen atoms. Refinement of the positional and isotropic temperature factors was carried out by full-matrix least-squares methods (CRYLSQ; Stewart, Kundell \& Baldwin, 1970) and $R$ was reduced to $0 \cdot 12$. Anisotropic refinement of the temperature factors further reduced $R$ to $0 \cdot 09$. At this stage a difference map revealed the $\mathrm{H}$ atoms at expected positions. Final refinement including the $\mathrm{H}$ 
atoms with an overall isotropic temperature factor of $B=4 \AA^{2}$ reduced $R$ to 0.068 . The weighting scheme was $w=1 / \sigma^{2}(F)$. Atomic scattering factors were taken from International Tables for X-ray Crystallography (1974). Atomic fractional coordinates and equivalent isotropic temperature factors with standard deviations are given in Table $1 .^{*}$

\section{Description and discussion}

Bond lengths and angles for the non-hydrogen atoms with their estimated standard deviations are given in Table 2. The $\mathrm{C}-\mathrm{H}$ distances range from 0.96 to $1.20 \AA$, with an average value of 1.08 (9) $\AA$. Other bond lengths involving $\mathrm{H}$ atoms are $\mathrm{O}-\mathrm{H}=0.90$ (9) and $\mathrm{N}-\mathrm{H}=1 \cdot 15(8) \AA$.

\section{Glucofurano-imidazolidine group}

Bond distances and angles in the imidazolidine ring agree well with the mean values reported for analogous glucofurano-imidazolidine-2-thione compounds (Conde, López-Castro \& Márquez, 1978). However, the

\footnotetext{
* Lists of structure factors and anisotropic thermal parameters have been deposited with the British Library Lending Division as Supplementary Publication No. SUP 35544 (11 pp.). Copies may be obtained through The Executive Secretary, International Union of Crystallography, 5 Abbey Square, Chester CH1 2HU, England.
}

Table 2. Bond distances $(\AA)$ and angles $\left(^{\circ}\right)$ for the non-hydrogen atoms

$\begin{array}{ll}\mathrm{C}(1)-\mathrm{N}(1) & 1.383(8) \\ \mathrm{C}(1)-\mathrm{N}(2) & 1.345(7) \\ \mathrm{C}(1)-\mathrm{O}(2) & 1.237(9) \\ \mathrm{N}(1)-\mathrm{C}(2) & 1.447(9) \\ \mathrm{N}(2)-\mathrm{C}(3) & 1.452(9) \\ \mathrm{C}(2)-\mathrm{C}(3) & 1.543(8) \\ \mathrm{C}(2)-\mathrm{O}(1) & 1.426(7) \\ \mathrm{O}(1)-\mathrm{C}(5) & 1.465(6) \\ \mathrm{C}(3)-\mathrm{C}(4) & 1.566(9) \\ \mathrm{C}(4)-\mathrm{C}(5) & 1.511(9) \\ \mathrm{C}(4)-\mathrm{O}(3) & 1.414(8) \\ \mathrm{N}(1)-\mathrm{C}(1)-\mathrm{N}(2) & 108.0(5) \\ \mathrm{N}(1)-\mathrm{C}(1)-\mathrm{O}(2) & 125.8(6) \\ \mathrm{N}(2)-\mathrm{C}(1)-\mathrm{O}(2) & 126.2(6) \\ \mathrm{C}(1)-\mathrm{N}(1)-\mathrm{C}(2) & 111.3(5) \\ \mathrm{N}(1)-\mathrm{C}(2)-\mathrm{C}(3) & 104.7(5) \\ \mathrm{C}(2)-\mathrm{C}(3)-\mathrm{N}(2) & 101.8(5) \\ \mathrm{C}(3)-\mathrm{N}(2)-\mathrm{C}(1) & 114.2(5) \\ \mathrm{N}(1)-\mathrm{C}(2)-\mathrm{O}(1) & 113.7(5) \\ \mathrm{O}(1)-\mathrm{C}(2)-\mathrm{C}(3) & 106.7(5) \\ \mathrm{C}(2)-\mathrm{C}(3)-\mathrm{C}(4) & 105.3(5) \\ \mathrm{C}(3)-\mathrm{C}(4)-\mathrm{C}(5) & 102.3(5) \\ \mathrm{C}(4)-\mathrm{C}(5)-\mathrm{O}(1) & 105.9(5) \\ \mathrm{N}(2)-\mathrm{C}(3)-\mathrm{C}(4) & 111.7(5) \\ \mathrm{O}(3)-\mathrm{C}(4)-\mathrm{C}(3) & 110.4(5) \\ \mathrm{O}(3)-\mathrm{C}(4)-\mathrm{C}(5) & 111.9(5)\end{array}$

$\begin{array}{ll}C(5)-C(12) & 1.525(10) \\ C(12)-O(4) & 1.419(6) \\ C(12)-C(13) & 1.514(9) \\ C(13)-O(5) & 1.452(10) \\ N(1)-C(6) & 1.428(7) \\ C(6)-C(7) & 1.405(10) \\ C(7)-C(8) & 1.400(9) \\ C(8)-C(9) & 1.370(11) \\ C(9)-C(10) & 1.389(11) \\ C(10)-C(11) & 1.394(8) \\ C(11)-C(6) & 1.384(10) \\ O(1)-C(5)-C(12) & 108.3(5) \\ C(4)-C(5)-C(12) & 115.8(5) \\ C(5)-C(12)-O(4) & 107.7(5) \\ O(4)-C(12)-C(13) & 111.9(5) \\ C(5)-C(12)-C(13) & 112.0(5) \\ C(12)-C(13)-O(5) & 108.2(5) \\ C(1)-N(1)-C(6) & 126.0(5) \\ C(2)-N(1)-C(6) & 122.5(5) \\ N(1)-C(6)-C(7) & 118.0(6) \\ C(6)-C(7)-C(8) & 119.3(7) \\ C(7)-C(8)-C(9) & 121.3(7) \\ C(8)-C(9)-C(10) & 119.2(7) \\ C(9)-C(10)-C(11) & 120.7(7) \\ C(10)-C(11)-C(6) & 120.1(6) \\ C(11)-C(6)-N(1) & 122.7(6) \\ & \end{array}$

Table 3. Least-squares planes through molecular

$\mathrm{N}(1)-\mathrm{C}(1)$ and $\mathrm{N}(1)-\mathrm{C}(2)$ bond lengths deviate significantly from the reported mean values $[1.351$ (3) and 1.471 (2) $\AA$, respectively]. The distance $\mathrm{O}(2)-\mathrm{C}(1)$ $=1.237$ (9) $\AA$ clearly indicates double-bond character and, therefore, some differences exist with respect to the thione compounds in which the resonance form

$$
s-c \sum_{N}^{N^{+}-}
$$

is important. The imidazolidine ring is planar as expected; shifts of the ring atoms from the least-squares plane are less than the standard deviations (Table 3). Atom $\mathrm{O}(2)$, not included in the plane calculation, lies on the plane.

Bond lengths and angles in the furanosyl ring agree with mean values reported for these compounds. The asymmetry of the endocyclic bonds $\mathrm{O}(1)-\mathrm{C}(2)=$ 1.426 (7) and $\mathrm{O}(1)-\mathrm{C}(5)=1.465$ (6) $\AA$ may be due to anomeric effects. Average values for the $\mathrm{C}-\mathrm{C}-\mathrm{C}$, $\mathrm{C}-\mathrm{C}-\mathrm{O}$ and $\mathrm{C}-\mathrm{O}-\mathrm{C}$ endocyclic angles of $103.6(5)$, $106.3(5)$ and $107.7(5)^{\circ}$ agree with mean values (Conde, López-Castro \& Márquez, 1978) and are comparable with those reported by Rahman \& Wilson (1972). The glucofurano ring is not planar, as shown by the deviations from the least-squares plane (plane II, Table 3) through the five atoms of the ring. In terms of ring-puckering coordinates (Cremer \& Pople, 1975), the amplitude-phase magnitudes are $q=0.33$ (1) $\AA$ and $\varphi=329.8(7)^{\circ}$ and the resulting conformation is intermediate between an envelope and a twist form. The fragments

(a) Equations of the planes

I: Imidazolidine ring

$$
0.8155 x-0.5342 y-0.2225 z=0.8863
$$

II: Glucofurano ring

$$
0.5548 x+0.4912 y-0.6715 z=5.3385
$$

III: Phenyl ring

$$
0.8775 x-0.3195 y-0.3626 z=2.8032
$$

(b) Atomic deviations $\left(\AA \times 10^{3}\right)$ from the planes

\begin{tabular}{lrlrlr} 
& \multicolumn{3}{c}{ II } & \multicolumn{2}{c}{ III } \\
$\mathrm{C}(1)$ & $5(6)$ & $\mathrm{O}(1)$ & $-84(4)$ & $\mathrm{C}(6)$ & $5(6)$ \\
$\mathrm{N}(1)$ & $-2(5)$ & $\mathrm{C}(2)$ & $142(6)$ & $\mathrm{C}(7)$ & $-2(7)$ \\
$\mathrm{C}(2)$ & $0(6)$ & $\mathrm{C}(3)$ & $25(7)$ & $\mathrm{C}(8)$ & $-7(7)$ \\
$\mathrm{C}(3)$ & $3(7)$ & $\mathrm{C}(4)$ & $-176(6)$ & $\mathrm{C}(9)$ & $11(7)$ \\
$\mathrm{N}(2)$ & $-4(6)$ & $\mathrm{C}(5)$ & $255(5)$ & $\mathrm{C}(10)$ & $-6(7)$ \\
$\mathrm{O}(2)^{*}$ & $7(5)$ & $\mathrm{C}(12)^{*}$ & $-409(6)$ & $\mathrm{C}(11)$ & $-3(7)$ \\
$\mathrm{C}(6)^{*}$ & $-106(6)$ & $\mathrm{O}(3)^{*}$ & $-1531(5)$ & $\mathrm{N}(1)^{*}$ & $-6(5)$ \\
$\mathrm{C}(7)^{*}$ & $142(7)$ & $\mathrm{O}(4)^{*}$ & $-57(5)$ & $\mathrm{C}(1)^{*}$ & $214(6)$ \\
$\mathrm{C}(11)^{*}$ & $-463(7)$ & $\mathrm{C}(13)^{*}$ & $-19(7)$ & $\mathrm{C}(2)^{*}$ & $-369(6)$
\end{tabular}

* Atoms not included in the calculation of the least-squares planes. 
Table 4. Selected torsion angles $\left({ }^{\circ}\right)$

$\mathrm{C}(5)-\mathrm{O}(1)-\mathrm{C}(2)-\mathrm{C}(3)$

$\mathrm{O}(1)-\mathrm{C}(2)-\mathrm{C}(3)-\mathrm{C}(4)$

$\mathrm{C}(2)-\mathrm{C}(3)-\mathrm{C}(4)-\mathrm{C}(5)$

$\mathrm{C}(3)-\mathrm{C}(4)-\mathrm{C}(5)-\mathrm{O}(1)$

$\mathrm{C}(4)-\mathrm{C}(5)-\mathrm{O}(1)-\mathrm{C}(2)$

$\mathrm{N}(1)-\mathrm{C}(2)-\mathrm{C}(3)-\mathrm{C}(4)$

$\mathrm{N}(2)-\mathrm{C}(3)-\mathrm{C}(2)-\mathrm{O}(1)$

$\mathrm{C}(1)-\mathrm{N}(2)-\mathrm{C}(3)-\mathrm{C}(4)$

$\mathrm{N}(2)-\mathrm{C}(3)-\mathrm{C}(4)-\mathrm{C}(5)$

$$
\begin{array}{r}
-24 \cdot 7(6) \\
4.4(6) \\
19 \cdot 3(6) \\
-31.3(6) \\
36 \cdot 1(6) \\
-116 \cdot 5(5) \\
121 \cdot 1(5) \\
111 \cdot 3(6) \\
-93.4(6)
\end{array}
$$

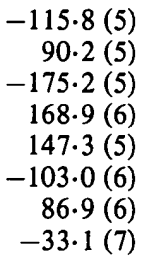

$\begin{array}{lr}C(3)-C(4)-C(5)-C(12) & -151.2(5) \\ C(2)-O(1)-C(5)-C(12) & 160.9(4) \\ C(4)-C(5)-C(12)-C(13) & 174.4(5) \\ C(4)-C(5)-C(12)-O(4) & -62.2(6) \\ O(1)-C(5)-C(12)-O(4) & 179.2(4) \\ O(1)-C(5)-C(12)-C(13) & 55.8(6) \\ C(5)-C(12)-C(13)-O(5) & 173.9(5) \\ O(4)-C(12)-C(13)-O(5) & 52.9(7)\end{array}$

small value of the torsion angle around the $\mathrm{C}(2)-\mathrm{C}(3)$ bond observed in this and analogous compounds may be due to distortion of the furanosyl ring due to the ring fusion.

The two rings show a cis form of coupling (Fig. 1). The relations $\beta=v_{1}-\delta, \gamma=\mu_{1}-\delta, \beta=\gamma$, derived for a cis fusion involving only ternary or quaternary $\mathrm{C}$ atoms (Geise, Altona \& Romers, 1967), approximately hold in this case, although some significant deviations are observed (see Table 4). Analogous distortions were observed for 1-( $p$-bromophenyl)-4,5(1,2-glucofurano)imidazolidine-2-thione (Vega, Hernández-Montis \& López-Castro, 1976) but not in other similar compounds (Jiménez-Garay, LópezCastro \& Márquez, 1974, 1976; Jiménez-Garay, Vega \& López-Castro, 1976; Moreno, García-Gea \& Hernández-Montis, 1976; Jiménez-Garay, Villares, López-Castro \& Márquez, 1978). The dihedral angle between the least-squares planes of the imidazolidine and furanosyl rings is $70.2(6)^{\circ}$.

\section{Molecular conformation}

The conformational and configurational details of the molecule in the crystalline state can be described by the torsion angles (Table 4). The phenyl ring, planar as expected (plane III of Table 3 ) and with an average $\mathrm{C}-\mathrm{C}$ distance of 1.390 (7) $\AA$ and $\mathrm{C}-\mathrm{C}-\mathrm{C}$ angle of $120.0(9)^{\circ}$, forms a dihedral angle of $15.1(6)^{\circ}$ with the imidazolidine ring. This value indicates a significant contribution of crystal-field forces to the phenylimidazolidine subrotation and differs from those observed in the compounds studied previously in which the dihedral angle ranges from 60 to $80^{\circ}$.

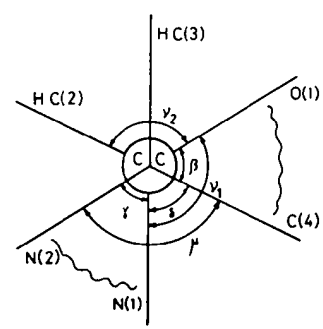

Fig. 1. Newman projection along the $\mathrm{C}(2)-\mathrm{C}(3)$ bond illustrating the ring fusion.

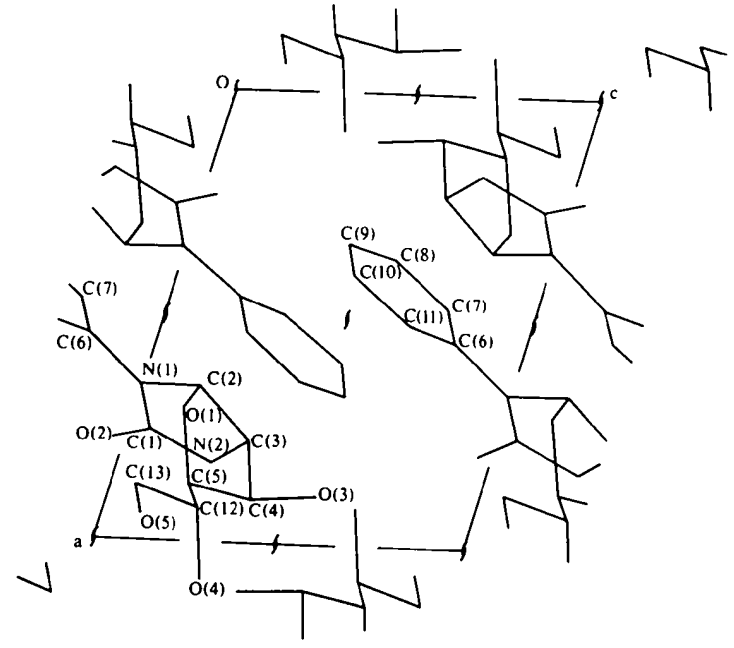

Fig. 2. Molecular packing as viewed down the $b$ axis.

Table 5. Intermolecular hydrogen bonds

$$
\begin{array}{ccccc} 
& \mathrm{O} \cdots \mathrm{O} & \mathrm{O}-\mathrm{H} & \mathrm{H} \cdots \mathrm{O} & \angle \mathrm{H}-\mathrm{O} \cdots \mathrm{O} \\
\mathrm{O}(4)-\mathrm{H} \cdots \mathrm{O}(2)^{1} & 2.793(7) \AA & 0.95(9) \AA & 1.85(9) \AA & 6(2)^{\circ} \\
\mathrm{O}(5)-\mathrm{H} \cdots \mathrm{O}(2)^{\prime \prime} & 2.765(8) & 0.86(9) & 2.02(9) & 25(2) \\
\multicolumn{5}{c}{\text { Symmetry code: (i) } 2-x,-\frac{1}{2}+y,-z ; \text { (ii) } x,-1+y, z .}
\end{array}
$$

\section{Crystal packing}

Fig. 2 shows the contents of the unit cell viewed down the $b$ axis. The structure consists of helical chains parallel to $b$. In these chains each molecule is linked by hydrogen bonds to the nearest neighbours related by a twofold screw axis. The $O \cdots O$ contact distance between $O(2)$ and $O(4)$ is 2.793 (7) $\AA$. Also, another contact exists between $O(2)$ and $O(5)$ of a molecule related by a $b$ translation. This contact, in spite of its non-linearity, could have hydrogen-bond character. Details of these contacts are given in Table 5. No other contacts shorter than the sum of the van der Waals radii have been detected.

The authors thank Professor Fernández-Bolaños for supplying the crystals and Professor A. López-Castro for helpful discussions. The present work is a part of a wider research project supported by the Government 
through the 'Comisión Asesora de Investigación Cientifica y Técnica'.

\section{References}

Conde, A., López-Castro, A. \& Márquez, R. (1978). Rev. Iberoam. Cristallogr. Miner. Metalog. 1, 23-36.

Cremer, D. \& Pople, J. A. (1975). J. Am. Chem. Soc. 97, $1354-1358$.

Fernández-Bolaños, J., García-GonzÁlez, F., Gasch, J. \& MENÉNDEZ, M. (1963). Tetrahedron, 19, 1883-1892.

Fritz, H. C. J. \& W ACKER, O. (1968). Helv. Chim. Acta, 51, $569-576$.

García-GonzÁlez, F., FernÁndez-Bolaños, J. \& Pradera, M. A. (1974). An. Quím. 70, 57-59.

Geise, H. J., Altona, C. \& Romers, C. (1967) Tetrahedron, 23, 439-463.

International Tables or X-ray Crystallography (1974). Vol. IV. Birmingham: Kynoch Press.

JimÉnEZ-GARAY, R., LóPEZ-CASTRo, A. \& MÁRQUEZ, R. (1974). Acta Cryst. B30, 1801-1805.
Jiménez-Garay, R., López-CASTro, A. \& MÁrquez, R. (1976). Acta Cryst. B32, 2115-2118.

JimÉnez-GaRAy, R., VEga, R. \& López-CASTro, A. (1976). Cryst. Struct. Commun. 5, 353-356.

Jiménez-Garay, R., Villares, P., López-Castro, A. \& MÁrquez, R. (1978). Acta Cryst. B34, 184-187.

KRUGER, F. \& Rudy, H. (1963). Justus Liebigs Ann. Chem. 669, 146-153.

Main, P., Hull, S. E., Lessinger, L., Germain, G., DEClerCQ, J. P. \& WoOlfson, M. M. (1978). MULTAN 78. A System of Computer Programs for the Automatic Solution of Crystal Structures from $X$-ray Diffraction Data. Univs. of York, England, and Louvain, Belgium.

Moreno, E., García-Gea, M. \& Hernández-Montis, V. (1976). Cryst. Struct. Commun. 5, 369-372.

Rahman, A. \& Wilson, H. R. (1972). Acta Cryst. B28, 2260-2270.

Stewart, J. M., Kundell, F. A. \& Baldwin, J. C. (1970). The XRAY 70 system. Computer Science Center, Univ. of Maryland, College Park, Maryland.

Vega, R., Hernández-Montis, V. \& López-Castro, A. (1976). Acta Cryst. B32, 1363-1366.

Acta Cryst. (1980). B36, 3052-3059

\title{
Deformation Electron Density of $\alpha$-Glycine at $120 \mathrm{~K}^{*}$
}

\author{
By Jean-Pierre Legros $\dagger$ ANd Åke Kvick $\ddagger$ \\ Institute of Chemistry, University of Uppsala, Box 531, S-751 21 Uppsala, Sweden
}

(Received 1 May 1980; accepted 18 July 1980)

\begin{abstract}
A study of the charge density in $\alpha$-glycine, $\mathrm{C}_{2} \mathrm{H}_{5} \mathrm{NO}_{2}$, has been carried out employing $\mathrm{X}$-ray and neutron diffraction data measured at $120 \mathrm{~K}$. The crystal is monoclinic, space group $P 2_{1} / n$, with the following cell dimensions: $a=5.084(1), b=11.820(2), c=$ 5.458 (1) $\AA$ and $\beta=111.95$ (2) ${ }^{\circ}$. The $\mathrm{X}$-ray data were collected in the $\sin \theta / \lambda$ range $0.00-1.20 \AA^{-1}$. The deformation densities were computed both by the $X-N$ method, using positional and thermal parameters from the neutron diffraction study, and by a multipole refinement method, where the asphericity in the electron charge distribution was accounted for in the refinement. Well defined peaks of deformation charge density are found in all covalent bonds. The positions of the peaks, however, vary slightly depending on the method used. The $X-N$ maps in the bonding regions are

\footnotetext{
* Hydrogen-Bond Studies. CXL.

+ Present address: Laboratoire de Chimie de Coordination du

$\ddagger$ Present address: Chemistry Department, Brookhaven National
} CNRS, 205 route de Narbonne, 31400 Toulouse, France. Laboratory, Upton, New York 11973, USA.
\end{abstract}

0567-7408/80/123052-08\$01.00 in agreement with theoretical $a b$ initio calculations, and with previous charge-density studies on $\alpha$-glycine and $\alpha$-glycylglycine.

\section{Introduction}

The direct analysis of electron densities in solids by means of diffraction techniques is presently widely employed. The effects of systematic experimental errors in the data and different approaches for extracting the information are, however, still much discussed. Here we report a study of the electron distribution in $\alpha$-glycine at $120 \mathrm{~K}$ using both combined $\mathrm{X}$-ray and neutron techniques $(X-N)$ and a multipole refinement technique. Details of the neutron diffraction study (Kvick \& Koetzle, 1980) will be presented in a later publication. A room-temperature electron density study of $\alpha$-glycine has been reported (Almlöf, Kvick \& Thomas, 1973), as have room-temperature and low-temperature $(82 \mathrm{~K})$ studies of $\alpha$-glycylglycine (Griffin \& Coppens, 1975; Kvick, Koetzle \& Stevens, 1979). It is of interest here to compare the results with theoretical calcu(C) 1980 International Union of Crystallography 